\title{
GLOBALIZAÇÃO CULTURAL NAS FRONTEIRAS O CASO DO FUTEBOL ESCOCÊS ${ }^{1}$
}

\author{
Cultural globalization on the borders: the \\ case of scottish football
}

\author{
Richard Giulianotti*
}

\begin{abstract}
RESUMO
Neste texto Giulianotti estuda a relação tensa existente entre identidade nacional e globalização, na experiência recente dos clubes e do selecionado nacional na Escócia, refletindo sempre o complexo contexto do Reino Unido.

Palavras-chave: História social do futebol; Futebol escocês; identidade nacional.
\end{abstract}

\begin{abstract}
In this text, Giulianotti studies the tense relations that exist between national identity and globalization in the recent experience of clubs and the national Scottish team, reflecting always the complex context of the United Kingdom
\end{abstract}

Key-words: Social History of football, Scottish football, national identity.

1 Tradução de Ana Maria Rufino Gillies. A pesquisa para este artigo foi possibilitada por uma bolsa do UK Economic and Social Research Council.

* Senior Lecturer em Sociologia na Universidade de Aberdeen, onde ele completou sua tese de doutorado em 1996. Ele é autor de Sociologia do futebol: dimensões históricas e socioculturais do esporte das multidões, (NOVA ALEXANDRIA, 2002) (publicada originalmente como Football: a sociology of the global game, Polity Press, 1999). Ele é co-autor de diversos livros sobre futebol, principalmente Fear and Loathing in world football (BERG, 2001), e Football culture: local conflicts, global visions (FRANK Cass, 1999). 
Se você perguntar a qualquer grupo de fãs de futebol escocês a respeito da ligação da Escócia com a América do Sul, é provável que a conversa gire em torno de dois aspectos chave do folclore sobre a Copa do Mundo. Primeiro, em 1978, a Escócia chegou na Argentina acreditando que estava madura o suficiente para competir contra os melhores, mas foi mandada de volta para casa na primeira rodada, após perder para o Peru. Segundo, houve encontros épicos contra o Brasil (1974, 1982, 1990, 1998), quando a Escócia ameaçou (mas no final não conseguiu) equiparar-se à nação de maior sucesso no futebol mundial. Argentina e Brasil expõem o insucesso do futebol escocês na era da globalização. Para muitos escoceses, estas passagens pelo futebol internacional também serviram para mostrar os limites da psique cultural escocesa: estão sempre à beira de realizar o sonho nacional, mas são perdedores perenes nos momentos cruciais. No contexto das pressões da globalização contemporânea, pode ser que este destino desesperado tenha se tornado a identidade soberana escocesa no palco global do futebol.

Neste texto, eu exploro o relacionamento do futebol escocês com os processos de globalização. Divido esta discussão em seis partes. Dada a relativa não familiaridade dos leitores desta revista com as peculiaridades da sociedade escocesa, começo apresentando alguns dos aspectos chave da história escocesa em termos de sociedade, cultura e as particularidades do futebol. Em seguida, faço uma discussão introdutória a respeito da ampla contribuição histórica da Escócia à globalização do futebol, após o que, dedico as duas seções seguintes a problemas atuais específicos enfrentados pelo futebol escocês em dois níveis: no futebol de clube, o Domínio do Old Firm; em termos nacionais, a diminuição do status e da influência do time da Escócia. Em quinto lugar, eu exploro os aspectos mais "mundanos" da globalização cultural no futebol; minha discussão sobre a cidade de Brechin é particularmente importante para o argumento de que globalidade molda e transforma muitas relações sociais nos níveis mais baixos da prática cultural. Finalmente, eu volto a considerar o futebol escocês como uma cultura de fronteira, permitindo o surgimento de identidades híbridas específicas ao lado de compulsões para "reterritorialisar", restabelecer sentidos de "lar". A análise extrai muito da literatura sobre a sociologia da globalização, particularmente o trabalho de Roland Robertson, Nestor Garcia Canclini e, mais criticamente, John Tomlinson. ${ }^{2}$

2 Para uma consideração sobre a ampliação global do futebol no século vinte, e sua relação com identidade nacional e classe, veja os primeiros dois capítulos em GIULIANOTTI (2002). 


\section{Escócia: Nação, Futebol e Identidade}

A Escócia tem uma população de pouco mais de cinco milhões de pessoas, e uma estimativa de mais uns vinte cinco milhões de descendentes diretos que moram em outros países, principalmente Inglaterra, Estados Unidos e nas antigas colônias do Canadá, Australia, Nova Zelândia e África do Sul. A maioria das pessoas na Escócia vive no "cinturão central" a sudoeste, entre a costa oeste (e a cidade mais populosa da nação, Glasgow, com 550.000 pessoas) e o leste (dominado pela capital da Escócia, Edinburgo, com 450.000 pessoas). As outras grandes cidades ficam mais ao norte, ao longo da costa leste: Dundee (145.000 pessoas) e Aberdeen (210.000 pessoas, mas com 225.000 incluindo a região em seus arredores). Os maiores grupos de imigrantes dentro da Escócia são aqueles que vêm cruzando o Mar Irlandês desde o século XVIII: Protestantes do norte da Irlanda, mas principalmente Católicos. Outros velhos grupos de imigrantes incluem números bem menores de italianos, poloneses e judeus; e asiáticos do sub-continente, desde a Segunda Guerra Mundial. Entretanto, a Escócia continua acentuadamente menos multicultural que a Inglaterra e o País de Gales.

Desde o Tratado da União selado em 1707, a Escócia tem sido parte do Reino Unido que também contém a Inglaterra, País de Gales e Irlanda do Norte. Apesar de o soberano britânico reter o maior poder político, econômico e militar, o tratado possibilitou à Escócia reter e desenvolver suas próprias instituições legais, religiosas, educacionais e de bem-estar social. O tratado facilitou a modernização e industrialização da sociedade escocesa durante os séculos XIX e XX, enquanto os escoceses contribuíram significativamente com a expropriação e administração das colônias britânicas de além-mar. Em 1979, houve um referendum na Escócia sobre a grande devolução dos poderes, mas a campanha do "sim" ficou $7 \%$ abaixo dos $40 \%$ necessários para estabelecer a devolução do governo. Após enfrentar uma dolorosa desindustrialização, elevados índices de desemprego, e o detestado governo conservador de Margaret Thatcher, o povo escocês votou "sim" em um novo referendum em 1997. Foi estabelecido um parlamento com devolução de poderes, equipado com poderes legislativos e de elevação de impostos, mas ainda emaranhado no sistema político do Reino Unido.

O parlamento escocês, baseado em Edinburgo e aberto em 1999, é um reflexo político da longa e duradoura distinção cultural. Várias formas complexas de dialeto escocês confirmam pela voz a diferença cultural entre escoceses 
(particularmente as classes trabalhadoras) e nativos de outras partes do RU. Nas artes, escritores tais como Kelman e Welsh, pintores como Currie e Howeson, e o compositor James MacMillan, destacaram as particularidades contemporâneas da consciência e identidade cultural escocesa (DEVINE, 1999, p. 608). Menos positivamente, as classes operárias escocesas, especialmente em Glasgow, são flageladas com as mais elevadas incidências de pobreza relativa no Reino Unido, principalmente no que se refere a quantidade de favelas e desemprego crônico; os problemas de saúde pública relacionados a doenças do coração, pulmões e fígado, além do vício de drogas (de nicotina e álcool, a heroina e crack-cocaína); e o uso fatal de armas (principalmente facas) durante violência interpessoal. $\mathrm{O}$ atual Poder Executivo escocês tem o compromisso de mudar a "vergonha secreta" do sectarianismo e intolerância da Escócia, que era inicialmente de natureza anti-católica e confinada ao cinturão central, mas que agora pode-se dizer incluir um racismo mais generalizado contra os não-europeus que buscam asilo, e mesmo algumas manifestações de anti-inglesismo ( DEVINE, 2000).

Na Escócia moderna, o futebol sempre dominou o esporte e grande parte da cultura popular, muito mais que em qualquer outra parte do Reino Unido. De acordo com um histórico relato popular, "fitba", como o esporte é conhecido por muitos escoceses, é "o único jogo" (FORSITH, 1990).O futebol escocês de clube atrai as maiores multidões per capita de todas as nações européias, exceto a Albania. Conforme veremos, o futebol escocês tem ricas dimensões hermenêuticas, facilitando a exploração e desenvolvimento de identidades culturais distintas.

O futebol escocês de clube demonstrou a existência de formas híbridas, freqüentemente antagônicas, de escotividade, particularmente através de elementos político-culturais do relacionamento da Escócia com a Irlanda e a Inglaterra. Desde os anos de 1890, os dois clubes de Glasgow - Celtic e Rangers (conhecidos conjuntamente como Old Firm dominam o futebol escocês. O Celtic foi fundado em 1888 para dar assistência aos católicos pobres, como forte foco do orgulho Irlandês-Católico e de algumas formas de nacionalismo irlandês. O Rangers (fundado em 1873) desenvolveu uma forte cultura protestante, sindicalista e anti-católica; foi somente em 1989 que eles acabaram com sua tradicional proibição de recrutar jogadores católicos. A intensa rivalidade entre os dois clubes causou a mais antiga competição do mundo, e os violentos conflitos entre sub-culturas torcedoras oponentes desde, ao menos, os anos de 1900. Em Edinburgo, o Hibernian foi fundado em 1875 por Católicos irlandeses, e seu rival de competições é o Heart de Midlothian. Em 
Dundee, os dois clubes líderes são o Dundee e o Dundee United - este último fundado pelos católicos irlandeses com o nome original de Dundee Harp. O Aberdeen é o outro grande clube de uma cidade de fora de Glasgow. A relativa ausência de sectarismo religioso ou de influência irlandesa no nordeste da Escócia fortaleceu a visão distintamente crítica dos torcedores do Aberdeen sobre o papel da "Questão Irlandesa" dentro do futebol escocês e da sociedade em geral (GIULIANOTTI, 1997). Agora, 42 clubes competem dentro das quatro divisões do sistema de liga escocesa; por esta razão, sempre existe a possibilidade de que um minúsculo clube como o Albion Roberts possa ser sorteado para jogar contra o Celtic ou o Rangers nas competições da copa nacional.

A nível internacional, competições contra times ingleses provocaram fortes sentimentos de diferença cultural, oposição e mesmo formas claras de antipatia contra os símbolos e concepções dominantes de inglesidade. A partida anual entre Escócia e Inglaterra é a mais antiga competição internacional do mundo, mas foi suspensa desde que o jogo em Glasgow, em 1989, provocou violentas brigas entre os fãs e mais de 250 prisões. Entretanto, para alguns nacionalistas, o nacionalismo cultural em torno dos jogos de futebol pode meramente simbolizar o fato de que a Escócia conta com a Inglaterra para ganhar uma identidade, mas também serve para distrair os escoceses da verdadeira batalha por independência política (JARVIE; WALKER, 1994; ver também NAIRN, 2001, p. 29).

Certamente, enquanto versões de "futebol folclore" eram jogadas na Escócia, o jogo de futebol moderno, de associação, foi trazido do norte da Inglaterra e rapidamente adotado no final do século XIX pela população operária industrial que se aburguesava. Nairn (2000) descreve os processos de "colonização em reverso", pela qual muitos escoceses precisavam viajar para a Inglaterra para deixar sua marca através de contribuições importantíssimas dentro do governo britânico, serviço público, indústria e mundo acadêmico. Se Nairn não conseguiu perceber uma posição tão negativa na cultura popular, ele sem dúvida compensou ao aplicar o conceito de "colonização em reverso" ao esporte. Na Inglaterra, foi o escocês William McGregor que promoveu a fundação do sistema de liga de futebol inglesa, e o arquiteto escocês Archibald Leitch que desenhou campos de futebol por toda a Grã-Bretanha. Entretanto, a colonização em reverso foi mais acentuada nas ondas de jogadores e técnicos escoceses que influenciaram muito o futebol inglês. Inicialmente, no final do século XIX, os "professores escoceses" eram escolhidos dentre os mais habilidosos jogadores disponíveis, que então eram recrutados profissionalmente 
por numerosos clubes ingleses. A linhagem subsequente de grandes jogadores escoceses, que "precisavam" se mudar para a Inglaterra a fim de provar suas habilidades e mostrar seu valor incluiu Hughie Gallagher (Newcastle United), Alex James (Arsenal), Dave MacKay (Spurs), Billy Bremmer (Leeds United), Denis Law (Manchester United), e Kenny Dalglish e Graeme Souness (Liverpool). Entre os dirigentes, Sir Matt Busby, Bill Shankly, e Sir Alex Ferguson foram orgulhosamente escoceses e dependentes de clubes ingleses para mostrar seus talentos como ganhadores de troféus.

O time nacional tem sido o foco principal de análise para aqueles que procuram pistas culturais da psicologia política da Escócia. Fãs escoceses geralmente vêem o time nacional como fadado a - invertendo um clichê do futebol-, ser arrancado das ondas da vitória pelas garras da derrota, ou a ganhar quando nada está em jogo. ${ }^{3}$ Nas finais de Copa do Mundo, a Escócia tendeu a perder pontos importantes para nações de futebol fraco (mais odiosamente, Costa Rica em 1990) enquanto venceu ou ameaçou times mais perigosos (tais como Holanda, Alemanha ou Brasil). A pior classificação veio em 1978, com a viagem à Argentina. Perder para o Peru e empatar com o Irã fez com que a Escócia precisasse vencer a Holanda por três gols para qualificar-se para os estágios mais finais. Os escoceses ganharam, mas apenas de 3 a 2, e voltaram para casa em desonra. Um ano mais tarde, houve o primeiro referendum de devolução [da soberania política], mas não conseguiu ganhar apoio suficiente dos escoceses. Alguns políticos consideraram que a derrota da "Argentina 78" minou a confiança coletiva dos escoceses na capacidade de moldar seu próprio futuro (WILSON, 1998). Hoje, aquele destino deve ser moldado cada vez mais dentro e ao longo de processos de globalização.

\section{Escócia, Futebol e Globalização: Tendências Históricas e Contemporâneas}

De acordo com Robertson (1992,p. 8), globalização é definida objetivamente pela crescente compressão de tempo e espaço, e subjetivamente pela crescente consciência de que o mundo é um só lugar. A globalização é o princí-

3 Entre outros bretões, os homens escoceses são algumas vezes chamados de Jocks. Para alguns comediantes ingleses, a tendência do futebol escocês de jogar bem no começo, mas decepcionar seus torcedores nos resultados, está baseada na condição médica pseudo-sexual conhecida como ejockulação prematura. 
pio axial da condição humana global, mas não procura simplesmente a homogeneização inexorável de gostos e práticas culturais ao redor do mundo. Em vez disso, a contínua heterogeneidade cultural que caracteriza a globalidade é refletida de duas formas. Primeiro, a globalização intensifica a "relativização" cultural, promovendo o surgimento de diferenças de identidade e a expectativa de que as particularidades culturais serão expressas de forma cada vez mais deliberada, elaborada e complexa. Em segundo lugar, o fenômeno cultural passa por "glocalização", quando os significados dos símbolos e produtos globais são adotados e adaptados pelas culturas locais para adequar-se às suas crenças, gostos e necessidades particulares (ROBERTSON, 1992, p. 173-174; 1995). Assim, através do esporte, nações "relativizam-se" contra os símbolos rivais de outras nações que fazem parte da competição internacional, enquanto "glocalização" é refletida nos distintos códigos estéticos e técnicas corpóreas nos quais culturas locais se envolvem dentro do jogo.

Robertson (1992, p. 59) argumentou que a globalização intensificou-se amplamente durante uma "fase inicial", de 1870 a 1920, em parte através da "miniglobalização" do colonialismo britânico e do comércio internacional. Estas conexões transcontinentais possibilitaram que os britânicos (especialmente os escoceses) difundissem seus esportes, incluindo o futebol, pelo mundo. Trabalhadores escoceses migrantes levaram o futebol a partes da Escandinávia e Rússia; soldados e professores escoceses introduziram o jogo no sul e oeste da África; e na América do Sul, escoceses tais como Archie McLean e Jock Hamilton, no Brasil; Alexander Watson Hutton em Buenos Aires, e John Harley em Montevideo ajudaram a introduzir o jogo entre as novas populações urbanas. Enquanto isto, em casa, a possibilidade de competições internacionais foi aberta quando a primeira partida deste nível foi disputada em 1872, entre a Escócia e a Inglaterra em Glasgow.

Os escoceses exerceram um papel crucial na globalização institucional e societal do futebol, estabelecendo clubes, competições e associações diretoras em locais distantes. Os britânicos fizeram pouco caso das iniciativas lideradas pelos franceses para estabelecer um corpo diretivo mundial; as quatro associações "nacionais" abandonaram a FIFA duas vezes na década de 1920, e não começaram a levar a Copa Mundial a sério até a década de 1960. Esta arrogância miótica fez com que os britânicos perdessem muito da sua possível influência dentro da Realpolitik do futebol internacional. Entretanto, pode ser que se os administradores britânicos de futebol tivessem sido liderados por escoceses mais pragmáticos, então parte da hegemonia britânica no futebol mundial poderia ter sido mantida (ASCHERSON, 2002, p. 234). De qualquer 
forma, as associações britânicas ainda têm uma influência institucional e societal significativa dentro do futebol mundial, através do controle de oito cadeiras no International Board que controla as regras do jogo.

Os jogadores escoceses foram rápidos em "glocalizar" o futebol, em termos de desenvolvimento e promoção de habilidades técnicas individuais avançadas e, em particular, os benefícios do trabalho de grupo e de passe. Isto contrastou significativamente com a ênfase mais aristocrática das exibições individuais de dribles e o método subsequente mais físico do futebol de "chutar e correr", na Inglaterra. Na cultura creola do Uruguai, um sinal precoce da hibridade do futebol emergiu no início do século XX, através da mistura das táticas de futebol inglesa e escocesa, com incrível sucesso, ganhando duas medalhas de ouro olímpicas e as finais da Copa do Mundo inaugural de 1930. Técnicos escoceses influenciaram fortemente o cultivo de estilos particulares nacionais e regionais, notavelmente a fluente escola danúbia de futebol durante o período de entre-guerras. Depois da II Guerra Mundial, com o crescimento das competições internacionais e as finais de Copa do Mundo, o estilo escocês tornou-se mais atavisticamente britânico em sua ênfase em robustez física e jogo combativo. A pior classificação veio nas finais da Copa do Mundo de 1954 na Suécia, quando a Escócia apanhou de 7 a 0 do Uruguai.

A "conectividade" global da televisão moderna, o aumento das competições de futebol internacional, a sofisticação estética dos jogadores estrangeiros, e os fracassos dos jogadores escoceses contra oponentes estrangeiros foram todos fatores que forçaram os jogadores, autoridades e torcedores na Escócia a reconceituar suas práticas e identidades de futebol dentro de um contexto de globalização. Em 1960, Hampden Park, em Glasgow, promoveu talvez a maior partida de jogos de clubes de todos os tempos - quando o Real Madrid derrotou o Eintrancht Frankfurt (7 a 3) e ganhou a Copa Européia -, para uma multidão composta essencialmente de mais de 130.000 espectadores locais. A partida teve um efeito profundo na Escócia, ao legitimizar o papel da competição internacional de futebol de clube. Sete anos mais tarde, o Celtic ganhou a Copa Européia, derrotando o Inter de Milão (2 a 1), em Lisboa, com um time de jogadores que tinham todos nascido dentro de um raio de 30 milhas do estádio do clube em Glasgow. Apesar de agüentar uma final intercontinental altamente violenta contra o Racing Club da Argentina em 1968, o futebol de clube escocês continuou a enfatizar a importância da relativização internacional. Em 1970, o Celtic perdeu a final da Copa Européia para o Feyenoord na prorrogação, e em 1974 eles foram derrotados nas semi finais pelo Atlético de Madri. Os Rangers ganharam a copa dos Vencedores da Copa de 1972 em 
Barcelona, e em Aberdeen levaram o mesmo troféu onze anos mais tarde derrotando o Real Madri por 2 a 1 em Gothenburg. O Dundee United perdeu a final da copa da UEFA em 1987 para o Gothenburg, enquanto o Celtic perdeu a final de 2003 para Porto Rico, em Sevilha, na prorrogação. Noutras partes, os jogadores escoceses contribuíram crucialmente para alguns dos times ingleses mais bem sucedidos na competição européia - notavelmente Law e Crerand no Manchester United; depois Burns, McGovern e Robertson no Nottingham Forest; e Hansen, Souness e Dalglish no Liverpool.

A nível nacional, a Escócia se qualificou para um recorde de cinco finais consecutivas da Copa do Mundo entre 1974 e 1990, mas nunca alcançou o segundo circuito do torneio. Durante a década de 1980, os técnicos da Escócia lutaram para convencer a nação que a prioridade do futebol deveria ser promover uma competição global em vez de campeonatos anuais contra a Inglaterra. Em termos de "memórias mundiais" do futebol, a principal contribuição da Escócia é relativamente modesta: o brilhante gol individualista de Archie Gemmil contra a Holanda em 1978.

Em termos de louvores e recordes, as multidões escocesas são acentuadamente mais bem sucedidas. No espaço de uma semana, em 1937, o Hampden Park estabeleceu dois recordes de público que permanecem intactos: por competição internacional, quando 149.500 compareceram ao jogo Escócia-Inglaterra; e para um jogo de clube, quando 147.300 compareceram à final da Copa Escocesa entre o Celtic e o Aberdeen. (Para ambas as competições, os números reais de público foram provavelmente mais próximos de 160.000). A multidão de Glasgow na final da Copa Européia de 1960, já mencionada, é um outro recorde. Em maio de 2003, os fãs do Celtic atingiram o número de 80.000, e possivelmente até 100.000 na final da Copa da UEFA em Sevilha - um público recorde para qualquer clube jogando em uma nação diferente. A nível internacional, os fãs da Escócia, conhecidos como o "Exército Xadrez", usaram as competições internacionais para projetar, em frente de novas audiências, uma forte identidade nacional escocesa, que é definida em grande parte por um comportamento turbulento, hedonista mas não violento, e uma declarada aversão pela Inglaterra e pelo inglesismo (GIULIANOTTI, 1991, 1995; FINN; GIULIANOTTI, 1998). O Exército Xadrez ganhou o prêmio oficial de fair play da FIFA e da UEFA por sua conduta gregária. Ainda assim, a óbvia paixão cultural do povo escocês por futebol está passando por pressões externas significativas através da transformação estrutural do jogo a nível de clube e internacional. 


\section{Dilema do futebol global 1: A Old Firm e a Liga Escocesa}

É de conhecimento geral que o futebol de clube europeu tem sido sistematicamente transformado por processos políticos, econômicos e culturais desde o final de 1980. Novas medidas-chave incluem o mandato Bosman da Corte Européia que enfatizou a mobilidade de jogadores como agentes livres; o valor multiplicado dos acordos de transmissão dentro de nações que possuem grandes canais de televisão; e a transmutação da Copa Européia em "Liga de Campeões" para atender os interesses do cartel dos G-14 que representa os 18 clubes mais poderosos da Europa. Na Escócia, a crescente influência de mercados livres e financeiros solidificou o domínio do Old Firm. Em 2001, a renda do Celtic e do Rangers ficou por volta de \$64 milhões e \$71 milhões respectivamente; os outros maiores orçamentos foram, cada um, de menos de \$13 milhões, de libras para os clubes Hearts e Hibernian de Edinburgo. Nenhum outro clube tem condições de contestar os salários e taxas de transferência do Old Firm. Assim, nenhum outro clube ganha a Liga Premier Escocesa (SPL) desde 1985, nem pega o segundo lugar desde 1995. Enquanto multidões estagnaram ou diminuíram na maioria dos clubes da SPL fora do Old Firm, os salários subiram, resultando em altos níveis de dívidas (PRICE WATERHOUSECOOPERS, 2002). Para "revitalizar" o sistema de liga, a liderança da SPL criou alguns truques de curta duração, tais como a "separação" da última temporada quando os seis melhores e os seis piores clubes dividem-se em suas próprias mini ligas.

A globalização do futebol de clube tem mais dimensões negativas para o Old Firm. Para a temporada de 2001-2002, o Celtic e o Rangers conseguiram com dificuldade incluirem-se entre os vinte clubes mais ricos do mundo, ${ }^{4}$ mas todos os outros clubes jogam nas maiores ligas mundiais - Espanha, Inglaterra, Itália e Alemanha-onde a renda da televisão é muito mais elevada. Enquanto o Manchester United (da Inglaterra) obteve mais de 30 milhões de libras esterlinas pela cobertura na televisão durante a temporada da English Premiership de 2002-2003, o Old Firm ganhou um mero 1.5 milhão de libras esterlinas resultante dos acordos do futebol escocês com canais de televisão. Estas disparidades mostram que o Old Firm não pode competir com clubes ingleses líderes nos mercados de trabalho do futebol

4 O Celtic e o Rangers ocuparam o $18^{\circ}$ e o $20^{\circ}$ lugares respectivamente. O Celtic teve a oitava maior audiência da Europa; o Rangers teria ficado entre os dez maiores se Ibrox tivesse conseguido mais 50.000. Entretanto, refletindo seus ganhos excepcionalmente restritos fora de campo, nenhum clube constou dos vinte maiores por transferência de gastos, nem entre os dez maiores por patrocínio de camiseta (World Soccer, Julho 2003). 
internacional, desta forma enfraquecendo seus desafios na competição européia e nos mercados consumidores do futebol global. Para tampar o buraco, os Rangers em particular acabaram constituindo imensos débitos (fala-se em $\$ 120$ milhões), mas nas condições econômicas enfraquecidas do futebol mundial atual aqueles déficits, embora de valor elevado, não significam tanto.

Estas diferenças tornam-se ainda mais problemáticas no contexto da consciência da globalização subjetiva aumentada dentro do futebol, entre os jogadores, autoridades de clubes e torcedores dentro do Old Firm. Todos estão cada vez mais preocupados em fazer sucesso em níveis mais altos, particularmente na Europa, acima das desvalorizadas competições escocesas. Aquela priorização é marcada pela maior exposição fenomenológica do povo escocês aos aspectos mundanos da globalização do futebol: a multiplicidade de partidas ao vivo de clubes europeus nos canais livres de televisão; a proliferação de futebol mercadoria internacional nos varejos de esportes nacionais; a constante disseminação de notícias e análises referente aos superstars e jogadores internacionais através das estações 24 horas de mídia esportiva. Como Hannerz (1992, p. 255) coloca, "o poder da mídia agora deixa todo mundo simplesmente um pouco mais cospomolitano". Para os fãs do Old Firm, o ideal de efetivamente competir contra times europeus líderes, de estabelecer uma "relativização" de identidade mais forte no cenário internacional, é cada vez mais pertinente. Estes processos de globalização também servem para inserir torcedores em clubes que não fazem parte do Old Firm, os quais nunca podem ter a esperança de efetivamente competir com times maiores fora da Escócia.

Nos últimos quatro anos, os maiores acionistas e diretores do Old Firm têm procurado ativamente novos mercados de televisão fora da Escócia. Uma alternativa, intermitentemente debatida, tem sido a fundação de uma liga "Atlântica" ou "Euro", na qual atuariam os clubes de maior sucesso das nações européias menores - em particular, Escócia, Holanda, Bélgica, Portugal e os países escandinavos. Esta forma criativa de miniglobalização poderia, em teoria, reunir uma possível audiência de televisão parecida com aquela da Alemanha e Inglaterra. Entretanto, a competição sofreria de uma potencial falta de prestígio histórico e competitivo.

A opção preferida é o Old Firm participar da English Premiership, possivelmente primeiro entrando na English First Division para depois ir em busca da promoção para a liga principal. A English Premiership é o maior torneio de liga do mundo em termos de renda, que chegou a atingir \$1.7 milhões em 2002. Através de uma rede pan-continental de estações de televisão 
controlada por Rupert Murdoch, várias competições inglesas ao vivo são transmitidas semanalmente na Europa, nas Américas, Ásia e Australasia.

Tanto a FIFA quanto a UEFA manifestaram sua oposição à possível mudança do Old Firm para a Inglaterra, sob a (incerta) alegação de que clubes não deveriam competir em competições de liga que estejam fora das suas fronteiras nacionais. Além disso, muitos dirigentes de clubes ingleses percebem a entrada do Old Firm em sua liga como um desafio adicional não bem-vindo aos saldos lucrativos na Premiership, principalmente na qualificação para a competição européia.

No entanto, os diretores do Old Firm insistem que sua entrada na Inglaterra "revitalizaria" a Premiership, aumentando seus lucros anuais em, ao menos, \$150 milhões. O Celtic e o Rangers já jogam ao longo e dentro da fronteira sociocultural da Inglaterra: eles possuem dezenas de milhares de torcedores no sul, recebem cobertura substancial da mídia de esportes "nacional" (RU); e particularmente no caso do Celtic, eles têm diversos treinadores e jogadores que aperfeiçoaram suas habilidades e construíram suas reputações nas mais importantes divisões do futebol inglês. Enquanto isto, muitos torcedores de outros clubes escoceses não têm nenhuma dúvida de que a saída do Old Firm beneficiaria culturalmente a liga escocesa, possibilitando que uma competição razoável se desenvolvesse, ao mesmo tempo removendo muito da inimizade sectária dos estádios. Financeiramente, o sistema de liga escocesa contrataria - mas isto encorajaria os clubes a orçar mais efetivamente em termos de despesas administrativas gerais -, os salários e transferências de jogadores. Também tem sido especulado que, ao mudar para a Inglaterra, o Old Firm daria aos seus jogadores escoceses locais uma chance maior de melhorar sua qualidade de jogo, desta forma ajudando o time nacional.

\section{Incertezas do Futebol Global 2: O Time Nacional}

A posição problemática do futebol escocês contemporâneo é agudamente evidenciada pelo time nacional. Há pouca dúvida de que o time escocês existente é o pior na memória viva, e notadamente inferior a seus colegas da Inglaterra ou de toda a Europa. Diferentemente de times escoceses anteriores, o time nacional não tem um único jogador que seja tecnicamente de classe mundial. Pela primeira vez na história do futebol, não há um jogador escocês que jogue regularmente nos principais clubes ingleses. O Old Firm tende a 
colocar em campo apenas um ou dois jogadores escoceses, tais como o já mais velho meio de campo do Celtic, Paul Lambert, ou o ex-capitão do Rangers, Barry Ferguson. Teme-se que a atual escassez de jogadores talentosos não seja um sinal histórico, mas estruturalmente determinado. Ano passado, a SFAAssociação Escocesa de Futebol -, mandou fazer uma importante investigação no futebol de juniores para identificar e remediar seus problemas.

O Old Firm acabou por substituir - em termos econômicos, políticos e simbólicos - o interesse "nacional". Até o começo de 1990, a Escócia tinha poucas dificuldades para encher Hampden Park com torcedores para competições internacionais. Entretanto, muitas partidas agora são jogadas para vastas quantidades de lugares vazios. Assim, como um fã do Celtic me disse, Hampden tornou-se a maior creche da Europa, pois milhares de ingressos baratos são dados para jovens estudantes: o famoso "Rugido de Hampden" tornou-se um coro de sopranos desafinados. Compare isto ao jogo médio da liga envolvendo o Old Firm quando Ibrox (Rangers) ou Celtic Park é geralmente preenchido com uma audiência combinada de 110.000 .

A drenagem financeira do futebol de clube escocês para fãs do Old Firm - em preços de temporada, merchandising e viagens de ida e volta a campeonatos (muitos deles na Europa) - prejudica sua capacidade de comparecer a campeonatos na Escócia. Como fãs de futebol que freqüentemente e propositadamente têm escolhido torcer por um time que está ganhando ou desafiando em nome das honrarias, os jogos da Escócia oferecem aos torcedores do Old Firm algumas possibilidades de sublimação emocional. Mais que isto, há a crescente percepção entre os fãs do Old Firm de que eles estão em conflito com a cultura de fãs da Escócia. Estes são vistos como compostos principalmente de fãs que vêm da costa leste da Escócia, ou por torcedores de clubes menores. Já, ao contrário, para alguns dos elementos mais agressivos dentro do Exército Xadrez, os fãs do Old Firm distanciaram-se simbolicamente da Escócia e da escocividade: torcedores do Celtic, através de seu tradicional hábito de exibir a bandeira tricolor irlandesa e de cantar algumas canções irlandesas; os fãs do Rangers, através de sua mais recente adoção de símbolos ingleses, tais como a bandeira e camisetas do futebol inglês. Sobretudo durante campeonatos contra o Old Firm (e em particular os Rangers), fãs de outros times escoceses algumas vezes cantam o hino nacional escocês, Flower of Scotland, para enfatizar seu nacionalismo cultural como forma de destacarse de seus rivais de Glasgow.

$\mathrm{O}$ argumento de que o Old Firm cresceu demais para além do futebol escocês talvez seja mais sucintamente sustentado através da preferência do jogador por clube em vez de país, notavelmente no caso do ex-jogador do 
Ranger, Barry Ferguson. Uma semana após o término da temporada de futebol 2002-2003, a Escócia jogou contra a Alemanha em Glasgow numa partida importantíssima para os campeonatos europeus de 2004. Em circunstâncias normais, Ferguson teria exercido um papel vital no meio de campo da Escócia; no entanto, por toda a temporada de clubes, ele constantemente jogou para os Rangers enquanto estava sofrendo de um problema pélvico crônico. O técnico do Rangers, Alex McLeish - um ex-jogador de partidas internacionais da Escócia, com 77 bonés $^{5}$ - insistiu que Ferguson não podia adiar sua cirurgia jogando pela Escócia, e assim deveria perder a competição para garantir que estivesse totalmente bem para o início da temporada de clubes de 2003-2004. Entre os fãs do Rangers, a decisão de McLeish não causou desagrado; e a imprensa escocesa prestou relativamente pouca atenção às ramificações da ausência de Ferguson.

A posição da Scottish Football Association em relação ao Old Firm parece com aquela do estado-nação em suas relações com corporações transnacionais (TNCs). Da mesma forma que o estado-nação, a SFAé um corpo governante que regula o mercado de futebol nacional. Seus parâmetros de ação são definidos pelas fronteiras nacionais, e somente estendidos através de sua participação como membro de corpos supraterritoriais, tais como associações continentais ou globais. Enquanto o Old Firm pode obter a maior parte das rendas dentro dos mercados nacionais, da mesma forma que as TNCs, eles recrutam mão-de-obra da elite internacional, procuram abrir novos territórios consumidores ao redor do mundo, e servem para introduzir o que Sklair (1991, p. 6) chamou de "ideologia-cultura do consumismo" via patrocínio e merchandising relacionados ao futebol. De acordo com os Novos Medievalistas em teoria política, os cidadãos não são mais leais a seu soberano nacional, mas construíram uma série de alianças e responsabilidades supranacionais para além do (e freqüentemente em conflito com o) estado-nação (GILPIN, 2001, p. 390-391). Da mesma forma, poder-se-ia imaginar aqui que o novo medievalismo do futebol envolveria a diminuição simbólica do time nacional pelas alianças de espectadores com clubes (especialmente o Old Firm) ou mesmo por marcas de roupas de esporte.

Não queremos com isto argumentar que o time nacional e o futebol escocês são meramente vítimas passivas da globalização dirigida pelo merca-

5 Toda vez que, na Inglaterra, Escócia, Irlanda ou País de Gales ele joga para um desses países em partidas internacionais, recebe um boné do país para o qual jogou. No caso de Alex McLeish, isto significa que ele jogou em 77 partidas internacionais, por isso ganhou 77 bonés. 
do. Como Weiss (1997) mostrou no contexto das regiões à Margem do Pacífico, os estados-nação exercem um papel ativo na globalização política e econômica dentro de suas regiões. Historicamente, como vimos, as autoridades do futebol escocês contribuíram muito significativamente para as dimensões legais, diplomáticas e técnicas da globalização do futebol. Atualmente, o Vice-Presidente da FIFA, David Will, é escocês, e o Diretor Técnico da UEFA é o ex-técnico da Escócia, Andy Roxburgh. O principal centro de treinamento da SFA, em Largs, atrai uma coleção genuinamente global de estudantes a seus renomados cursos de técnico. Mais recentemente, a SFA tentou (mas não conseguiu) garantir o direito de co-anfitriar (com a Irlanda) os Campeonatos Europeus de 2008, mas conseguiu garantir que Glasgow fosse a sede da final da Liga de Campeões entre Real Madrid e Bayer Leverkusen. Se o Old Firm quisesse juntar-se a uma outra liga fora da Escócia precisaria do acordo regulativo da SFA.

O compromisso mais forte da SFA com os processsos de globalização ocorreu nos recrutamentos do ex-técnico e jogador alemão Berti Vogts para dirigir o time nacional, e seu compatriota Rainer Bonhof para técnico do time Under-21 [Sub 21]. Vogts é o primeiro dirigente estrangeiro da Escócia, e sua nomeação foi mais uma cópia do recrutamento inglês de Sven-Goran Eriksson para técnico. Por razões mais pragmáticas que nacionalistas, os fãs escoceses são ambivalentes com relação a Vogts: eles ficam estupefados com suas táticas e deprimidos com os resultados. Até o momento, o pior desempenho deles em mais de uma década foi a Escócia ter conseguido um empate no último minuto contra as Ilhas Faroe (população: menos de 46.000) em Setembro de 2002. Enquanto isto, os jornalistas e fãs alemães mostraram aos escoceses as deficiências técnicas de Vogts.

Assim, um pouco de realpolitik é necessário para avaliar a posição da SFA referente à globalização. A nomeação de Vogts sugere que uma pequena nação como a Escócia simplesmente não pode igualar-se a competidores maiores quando quer engajar-se positivamente dentro de mercados globais. Em outras palavras, as dimensões econômica, política e cultural de globalização implicam todos os tipos de sociedade, e germinam algumas formas incomuns e inesperadas de conectividade global. Porém, elas também fazem surgir "geometrias de poder" distintas que reproduzem desigualdades distintas, dentro e fora do campo. 


\section{Globalização Mundana: a FIFA em Brechin}

John Tomlinson (1999) argumentou que a experiência de globalização cultural não está restrita a grupos sociais de elite, mas implica grandemente todas as sociedades, independentemente de riqueza. Tomlinson observa, via Dick Hebdige (1990), que a grande proliferação de "cosmopolitanismo mundano" é dirigida em parte pela disponibilidade de tecnologia barata, principalmente a televisão. Em nações desenvolvidas como a Escócia, por exemplo, nosso cosmopolitanismo mundano dentro do futebol é ressaltado pela onipresença de aparelhos de televisão nos lares, permitindo que campeonatos da Liga dos Campeões ou Copa do Mundo sejam vistos em canais gratuitos de televisão; nas super lojas locais de cidades pequenas como Brechin, nós encontramos kits de times nacionais sul-americanos e de times de clubes líderes; e nas bancas de jornais, encontramos revistas de futebol e de esporte, em geral direcionadas aos mercados infantis e adulto, com uma crescente ênfase no jogo global (acima do nacional).

Entretanto, como a discussão anterior sugeriria, eu considero um problema a incapacidade de Tomlinson teorizar adequadamente a geometria do poder de globalização. Tomlinson não consegue ultrapassar a noção de que apenas "pontos limiares" muito básicos parecem merecer atenção em relação ao relacionamento da estratificação social com a cultura global. Colocando de forma grosseira, atores sociais requerem valores financeiros significativos para obter elevados níveis de participação no cosmopolitanismo mundano de futebol para: a assinatura de estações de TV pagas que oferecem canais exclusivos de esporte; a réplica em constante mudança de kits de times de futebol internacional; a literatura sobre o jogo global. Certamente, assinantes das classes trabalhadoras se fazem altamente representados entre os sete milhões de lares que pagam até US\$60 por mês para receber o canal de televisão Sky. Ainda assim, esta Commodification de cultura global está bem além de um patamar que todas as classes sociais podem facilmente arcar. Além disto, ele come parte do orçamento de famílias e de aposentados da classe trabalhadora muito mais que dos casais de classe média alta. Em futebol, a geometria de poder dentro do cosmopolitanismo mundano também é refletida nas agudas divisões entre elite e outros grupos. Na Escócia, as maiores lojas da High Street do Reino Unido tendem a mostrar apenas camisas do Old Firm, juntamente com aquelas de times ingleses e estrangeiros. Nos canais gratuítos de televisão, é apenas o Old 
Firm que é mostrado ao vivo, contra a competição européia em campeonatos de prestígio, no meio da semana.

Ainda assim, as ambigüidades da globalização mundial são tais que, para clubes escoceses que não o Old Firm, nem todas as experiências são negativas. Diversos clubes SPL mostraram tanto as finanças apertadas quanto a avançada globalidade dentro do futebol escocês ao recrutar uma grande quantidade de jogadores baratos de outras nações. Nos últimos anos, os principais jogadores do Dundee incluíam os argentinos Claudio Caniggia, Fabian Caballero, e Beto Carranza, e os georgianos Giorgi Nemsadze e Temuri Ketsbaia. Quando Livingston terminou em terceiro lugar no SPL, na temporada 20012002, a maioria dos jogadores regulares eram de fora do Reino Unido. Em Junho de 2003, Livingston também recrutou o ex-técnico brasileiro do sub 20, Marcio. Mesmo no Raith Rovers - um pequeno time de Kirkcaldy que joga na Primeira Divisão escocesa -, o jogador-técnico é o espanhol Antonio Calderon, que recrutou diversos jogadores hispânicos e comunica-se com o time na sua língua nativa. ${ }^{6}$

Minha pesquisa continua em um pequeno clube, Brechin City, ressaltou alguns elementos distintivos de globalidade cultural dentro dos pontos mais profundos do futebol escocês. Brechin é uma pequena cidade (com catedral) localizada a cerca de vinte milhas ao norte de Dundee, com uma população de aproximadamente 6.000 habitantes. Brechin City foi fundada em 1906, entrou para a Scottish League em 1923, e no meio da década de 1960 sobreviveu a uma tentativa conjunta de outros clubes liderados pelos Rangers para eliminar o clube e outros quatro times pequenos. Na lista de honrarias do clube consta apenas a vitória em campeonatos de divisões menores no sistema da Scottish League. Uma coisa incomum no futebol escocês é o fato de Brechin City não pertencer a nenhum indivíduo privado ou grupo de acionistas, mas ser, em vez disso, uma associação que pertence a seus membros assinantes, os quais elegem uma mesa diretora. Parcialmente por causa dessa democracia institucionalizada, o clube atrai uma grande torcida local, com uma multidão média de mais de 700 para a temporada de 2002-2003. O estádio do clube, Glebe

6 É claro que a conectividade e desterritorialização global também são utilizadas por culturas relativamente marginais dentro do futebol escocês. Por exemplo, websites que são administrados por grupos auto-denominados hooliga atraem browsers e mensagens do mundo todo. Tais foruns assim aparecem como 'esferas públicas subculturais', nas quais a estética, ética e práticas de violência no futebol adquirem cada vez mais texturas cosmopolitas. Naquele que talvez tenha sido o mais espetacular caso de auto-promoção cosmopolitana por parte de um grupo hooligan escocês, a formação conhecida como o Aberdeen soccer casuals contratou um quadro de anúncios para a competição da Copa da UEFA contra Hertha Berlin, em Berlim, durante a temporada de 2002-2003. 
Park, é mais conhecido por causa de uma cerca viva que tem até a metade do campo sobre o terraço oposto à plataforma principal. As finanças do Brechin são tão reduzidas que só permitem que jogadores sejam contratados à base de meio período.

Três elementos do relacionamento de Brechin City com a globalização valem a pena serem mencionados aqui. Primeiro, e o mais notável, em termos sócioinstitucionais, através de David Will, o Brechin possui uma conexão pessoal direta com os mais elevados escalões do mundo do futebol. Will é um advogado local, e ex-chairman e atual Presidente Honorário do Brechin City que atingiu proeminência atuando como um advogado articulado e vigoroso durante a luta do clube em meados de 1960. Will é o Vice-Presidente britânico na Executiva da FIFA, e é particularmente responsável pelos assuntos legais, de segurança e relacionados ao "fair-play". Ele continua a comparecer a tantos campeonatos do Brechin City quantos possíveis, e foi uma testemunha emocional das consecutivas promoções do clube da Terceira e Segunda Divisões nas duas últimas temporadas.

Segundo, a torcida do clube possui alguma globalidade sócio-cultural, sobretudo com relação a alguns expatriados nos Estados Unidos e a possibilidade de acessar o website oficial, embora as mensagens sejam tipicamente de torcedores locais. As desigualdades dentro da globalidade mundana do futebol são algumas vezes comentadas pelos torcedores, por exemplo ao contrastar a disponibilidade (ou o contrário) do merchandising de Brechin City àquele de clubes escoceses e europeus mais importantes, quer seja no E-Bay ou em lojas de esporte locais. Alguns dos torcedores do Brechin também acompanham clubes escoceses maiores; aqueles que acompanham o Old Firm, no entanto, ganham um ponto de entrada no futebol de clube europeu.

Terceiro, como observa Robertson (1992, p. 164-181), algumas respostas culturais à globalidade enfatiza formas profundas de particularidades: estas incluem o aumento de movimentos fundamentalistas (tais como formações religiosas, nacionalistas, ambientais ou localistas), e a mudança na direção de um entusiasmo romantizado e nostálgico para o modo Gemeinschaft de identidade coletiva. ${ }^{7}$ À primeira vista, poder-se-ia esperar que os elementos chave da condição sócio-política do Brechin City promovessem uma particularidade intensiva: notavelmente a idade do clube, o status da liga, a estrutura corporativa, a demografia local, e características básicas incomuns. Entretanto, um fundamentalismo romantizado não é obvio entre os torcedores do Brechin, por fortes razões sócio-culturais. Não há nenhuma “invenção de tradições” dentro

7 O autor refere-se ao conceito de gemeinschaft tal como ele é enunciado por Ferdinand Tönies, para quem à comunidade (cujos vínculos de coesão são baseados na tradição e nas afinidades eletivas) antepõem a Gesellschaft, sociedade, cujos vínculos são de natureza contratual. N.T. 
da torcida, em termos de construção de identidade coletiva com forte referência a um passado artificialmente construído.

Stauth e Turner (1988) indicam que nostalgia é caracterizada em parte pela imaginação de uma história em termos de perda coletiva, o fim do todo, e a erosão de expressividade. Contudo, estas disposições sócio-históricas não estão particularmente visíveis dentro da cultura do futebol de Brechin. Os torcedores tendem a ver os destinos do clube como relativamente cíclicos: "tem tempos bons, e tem tempos ruins, é assim que as coisas são" como me disse um fã de longa data. O staff de jogadores do clube ainda é visto como tendo seu caráter "incorrigível", notavelmente seu técnico atual e artilheiro principal. Embora os fãs do clube estejam cientes das "lendas" históricas, a leonização do passado não é uma hermenêutica proeminente; em vez disso, o foco está principalmente no "presente" socio-temporal, isto é, nas últimas poucas partidas, nas próximas poucas partidas, e o resto da atual temporada de futebol.

Em Brechin, a possibilidade de gemeinschaft relativamente fechado está particularmente circunscrita. A segregação de multidões é rara nas divisões mais baixas do futebol escocês. Evitando-se assim esta divisão socioambiental específica entre os torcedores, erradica-se uma fonte interativa de fundamentalismo mais forte entre os fãs. Além disso, as gerações de torcedores cresceram com o fato de que é raro qualquer um dos jogadores de clube viver em Brechin. Hoje, a maioria dos jogadores vêm do cinturão central, onde quase todas as sessões de treinamento de meio de semana ocorrem.

O caso de Brechin confirma que, embora todos os clubes escoceses procurem "particularizar-se" para distinguirem-se em termos de identidade cultural, nos níveis mais baixos do futebol na Escócia não há isolacionismo fundamental voltado às conseqüências desterritorializantes da globalização do futebol. Há um forte senso de vitalidade e renovação cultural dentro daquelas instituições de futebol que estão situadas fragilmente dentro das novas geografias de poder construídas através da globalização.

\section{As Futuras Fusões do Futebol: Culturas de Fronteira e Reterritorialização}

García Canclini (1995), em seu estudo sobre modernidade e globalização em Tijuana, México, ofereceu dois argumentos pertinentes a este estudo. Primeiro, 
ele observa que "territórios de fronteira" são os mais claros domínios da globalização contemporânea, procurando a intensiva hibridização de formas e práticas culturais. García Canclini conclui que dada a experiência onipresente de desterritorialização cultural, "hoje todas culturas são culturas de fronteiras" (1995, p. 261). Segundo, ele indica que, em contextos de transformação sócio-cultural e deslocamento de populações, as pessoas ainda procuram estabelecer suas identidades de acordo com um lar definível, a fim de reivindicar algum tipo de custódia cultural e de "reterritorializar-se" entre os levantes físicos e simbólicos de globalidade.

As observações de García Canclini podem ser transferidas para a exploração das transformações que estão ocorrendo no futebol escocês. Primeiro, o futebol escocês sempre esteve metaforicamente "nas duas fronteiras" em dois sentidos. No oeste, o relacionamento com a Irlanda serviu para promover a fundação de numerosos clubes, e foi institucionalizado através das histórias culturais sectárias de Rangers e Celtic. No sul, como o relacionamento do México com os Estados Unidos, o futebol escocês tem uma longa conexão histórica com um vizinho mais poderoso - um relacionamento definido em grande parte em termos de dependência sócio-econômica, mas também marcado pela complexidade cultural de processos de globalização intensificados. O desenvolvimento do futebol inglês deve tanto aos escoceses, a ponto de podermos nos referir ao "futebol inglês" como uma construção essencialmente híbrida. Por outro lado, a maioria dos fãs de futebol tem um conhecimento substancial do jogo inglês e, ao menos na televisão, é provável que tenham assistido mais jogos envolvendo clubes ingleses que escoceses.

É no território de fronteira entre Inglaterra e Escócia (Premiership/Old Firm) que estamos testemunhando as mais fortes pressões contra a desterritorialização formal de construções institucionais-legais entre nações de futebol. Em nenhum outro relacionamento de fronteira, entre nações de futebol, nós testemunhamos tais inter-relações complexas e de longa duração, a nível econômico, social, político e cultural. Em nenhum outro relacionamento de fronteira os argumentos econômicos e normativos são a favor do colapso de barreiras nacionais entre as ligas, nem exercem tanta pressão como na luta do Old Firm para entrar no jogo inglês.

Desterritorialização e re-territorialização estão causando impacto nos clubes que não fazem parte do Old Firm. Isto é mais óbvio em relação à mudança de estádios para reduzir as perdas: atualmente o Hiberninan e Hearts estão comprometidos com o compartilhamento de um novo estádio nos arredores de Edinburgo; Dundee e Dundee United também estão explorando as possibilidades de compartilhar áreas; Aberden e Falkirk estabeleceram fundos e capital 
de projetos para construir novos estádios. Ainda assim, em termos de identificação cultural, a reterritorialização simbólica pode ser particularmente óbvia, envolvendo as tentativas do Old Firm para ligar-se a torcedores não-escoceses. Por exemplo, entrar no Premiership possibilitaria ao Celtic adquirir maior prestígio cultural no exterior, e a propagandear o clube não apenas como pertencendo a Glaswegianos ou Irlandeses-Católicos escoceses, mas como a quintessência das instituições de futebol irlandês - conseqüentemente tornando-se atraente inter alia àqueles cinqüenta milhões de norte-americanos que reivindicam algum tipo de ancestralidade irlandesa.

A desterritorialização mundana já está incorporada na conectividade sóciocultural de grupos de torcedores. Mais obviamente, a Internet fornece numerosos canais e websites de chat devotados a clubes em particular. Os fãs do Celtic, por exemplo, têm um website que relaciona centenas de "pubs celtas" no mundo, onde eles serão bem recebidos. Os avanços tecnológicos e o abaixamento dos custos de telecomunicações promoveram uma proximidade maior dos fãs mais distantes a seus clubes. No começo da década de 1980, os fãs do Celtic na Austrália só podiam acompanhar as sortes de seu time nas finais da Copa escocesa ouvindo, via telefonemas transatlânticos, transmissões ao vivo de rádio escocesas. Hoje, estas partidas são transmitidas instantaneamente via satélite, enquanto mais torcedores comparecem a estes jogos devido ao custo relativamente baixo de vôos transatlânticos. O Celtic, enquanto isto, tornou-se o primeiro clube do Reino Unido a transmitir um campeonato ao vivo na Internet (veja http:// www.lssport.com/celtic20010515.pdf). Assim, a geometria do poder da conectividade global permanece fortemente inclinada a favor dos mercados destes clubes maiores; os fãs de times menores da SPL ainda lutam para assistir seu time ao vivo, particularmente em partidas que não envolvem o Old Firm.

A nível internacional, a reterritorialização ocorre na reconstrução imaginativa da Escócia e da identidade escocesa. Conforme observado anteriormente, muito da reputação internacional do Exército Xadrez foi construída através de rituais que seus participantes adotam para mostrar uma imagem oposta às imagens mais negativas dos fãs ingleses: "os fãs da Escócia não são hooligans ingleses" foi sua mensagem essencial de identidade (FINN; GIULIANOTTI, 1998). O contexto político cultural para aquela auto-definição negativa foi liquidado: o Poder Executivo escocês pode ter novas formas de autonomia política e validação coletiva, mas os escoceses não desprezam o governo trabalhista em Londres tanto quanto desprezam a administração conservadora anterior. Há um sentimento mais forte de que a identidade dos torcedores escoceses deveria ser mais positiva, mais voltada para fora, para o mundo e européia, em vez de dependente de injustiças políticas e desigualdades morais percebidas como vindas do sul. Entretanto, o abandono da identidade de torcedor 
escocês anti-inglês é um processo gradual e culturalmente complexo. Muito do antagonismo dos fãs escoceses contra a Inglaterra está enraizado na cultura do futebol como, por exemplo, na condescendência que é percebida nos comentaristas ingleses (na rede de televisão do Reino Unido) contra os jogadores e clubes escoceses, ou na descrição propositadamente seletiva da mídia do RU dos melhores atletas escoceses como "britânicos" em vez de "escoceses". A manutenção tenaz da identidade esportiva escocesa-não-inglesa foi realçada quando um político nacionalista escocês foi amplamente ridicularizado por argumentar que o povo escocês deveria apoiar a Inglaterra durante as finais da Copa do Mundo de 2002.

\section{Comentários finais}

Como vimos, o futebol escocês tem sido o maior jogador na globalização do futebol desde a fase de take-off no final do século XIX e início do XX. O futebol escocês está sentindo com acuidade particular os processos de globalização que transformaram o jogo global. A identidade nacional escocesa foi pressionada a relativizar sua postura anti-inglesa. A desigualdade da globalização faz com que o time nacional escocês, e os atores institucionais mais inferiores dentro do futebol de clube escocês, estejam relativamente menos aptos para aproveitar as possibilidades da globalidade para promover seus próprios interesses. Há agora uma necessidade urgente de jogadores escoceses para re-glocalizar seus estilos e táticas de jogo a fim de revitalizar o interesse doméstico no time nacional e melhorar sua posição internacional. Em número e intensidade de torcedores, o Old Firm está entre os maiores clubes, mas falta liberdade constitucional para entrar naquelas competições extra-escocesas que permitiriam que eles competissem mais efetivamente com rivais das grandes ligas na Inglaterra, Alemanha, Itália e Espanha.

Formas intrigantes de desterritorialização e re-territorialização serão exploradas em anos futuros. A idéia de uma Escócia moderna é em si uma construção muito híbrida, uma vez que a nação há muito tempo possui uma grande comunidade de expatriados e relações de dependência com a Inglaterra juntamente com complexas ligações com a Irlanda. No futebol, como vimos, o time de futebol nacional está passando por uma desterritorialização na identidade de técnicos e de fãs; tal processo está em perigo por causa da possibilidade da Escócia perder a chance de relativização, não se qualificando para futu- 
ros torneios internacionais. Mais fortemente, a reterritorialização tem forte potencial de ocorrer dentro do Old Firm, primeiro rompendo sua identidade de fronteira e entrando na Inglaterra, e segundo, como conseqüência, construindo mercados no meio de espectadores receptivos no exterior, principalmente na América do Norte. Para o Celtic, como observado, isto teria como resultado favorável à construção de uma identidade de clube enraizada em irlandade. Para o Rangers, sua apresentação como a quintessência "britânica" (isto é, Unionista) de clube seria muito lucrativa no futuro, especialmente na Inglaterra e nos velhos domínios coloniais. Estas identidades de Old Firm poderiam ter um efeito de tesoura na escocividade do futebol de clube. Em ambos os casos, o espaço para expressão de uma identidade de clubes distintamente escoceses seria aproveitado sem remorso. Em tais circunstâncias, a própria idéia da Escócia competindo com esperança, mesmo efetivamente, contra o Brasil e outros times da América do Sul seria consignada aos livros de história. Aqui ao menos nós teríamos a confirmação escocesa da observação de Robertson (1992, p. 6) que a globalização "não é em si uma coisa boa", apesar de certas indicações de "progresso mundial".

\section{Referências}

ASCHERSON, N. Stone Voices: The Search for Scotland. London: Granta, 1999.

DEVINE, T. M. The Scottish Nation 1700-2000. Harmondsworth: Penguin, 1999.

DEVINE, T. M. Scotland's Shame? Bigotry and Sectarianism in Modern Scotland. Edinburgh: Mainstream, 2000.

FINN, G. P. T.; GIULIANOTTI, R. Scotland Fans Not English Hooligans! In: BROWN, A. (Ed.). Fanatics! London: Routledge, 1998.

FORSYTH, R. The Only Game: the Scots and World Football. Edinburgh: Mainstream, 1990.

CANCLINI, G. N. Hybrid Cultures: Strategies for Entering and Leaving Modernity. Minneapolis: University of Minnesota Press, 1995.

GILPIN, R. Global Political Economy. Princeton, NJ: Princeton University Press, 2001.

GIULIANOTTI, R. Scotland's Tartan Army in Italy: The Case for the Carnivalesque. Sociological Review, v. 39, n. 3, p. 503-527, 1991. 
Football and the Politics of Carnival. International Review for the Sociology of Sport, v. 30, n. 20, p. 191-223, 1995.

.Enlightening the North: Aberdeen fanzines and local football identity ' In: ARMSTRONG, G.; GIULIANOTTI, R. (Eds.). Entering the Field: New Perspectives in World Football. Oxford: Berg, 1997.

. Sociologia do Futebol: Dimensões Históricas e Socioculturais do Esporte das Multidões. São Paulo: Nova Alexandria, 2002.

HANNERZ, U. Cultural Complexity. New York: Columbia University Press, 1992.

HEBDIGE, D. Fax to the Future. Marxism Today, Jan. 1990.

JARVIE, G.; WALKER, G. (Eds.). Scottish Sport in the Making of the Nation: Ninety Minute Patriots? London: Leicester University Press, 1994.

NAIRN, T. After Britain: New Labour and the Return of Scotland. London: Granta, 2000 .

NAIRN, T. Mario and the Magician, New Left Review, n. 9, p. 3-24, 2001.

PRICEWATERHOUSECOOPERS The Search for a Viable Playing Field: Financial Review of Scottish Football Season 2000/1. Glasgow: PricewaterhouseCoopers, 2002.

ROBERTSON, R. Globalization. London: Sage, 1992.

ROBERTSON, R. Glocalization: Time-Space and Homogeneity-Heterogeneity. In: FEATHERSTONE, M.; LASH, S.; ROBERTSON, R. (Eds.). Global Modernities. London: Sage, 1995.

SKLAIR, L. Sociology of the Global System. Baltimore, MD: John Hopkins University Press, 1991.

STAUTH, G.; TURNER, B.S. Nostalgia, Postmodernism, And The Critique Of Mass Culture. Theory, Culture \& Society, v.5, n. 2-3, 1988.

TOMLINSON, J. Globalization and Culture. Cambridge: Polity, 1999.

WEISS, L. Globalization and the Myth of the Powerless State. New Left Review, n. 225, p. 3-27, 1997.

WILSON, M. Don't Cry for Me Argentina: Scotland's 1978 Argentina Adventure. Edinburgh: Mainstream, 1998. 